\title{
Korunan alanlarda çevre sorunlarının değerlendirilmesi: Pamukkale özel çevre koruma bölgesi
}

\author{
Evaluation of environmental problems in protected areas: case study of Pamukkale specially protection area
}

Veysel DAĞ, Sibel MANSUROĞLU

Akdeniz Üniversitesi, Mimarlık Fakültesi, Peyzaj Mimarlığı Bölümü, Antalya, Türkiye

\section{Eser Bilgisi / Article Info}

Araştırma makalesi / Research article DOI: $10.17474 /$ artvinofd.296529

Sorumlu yazar / Corresponding author Veysel DAĞ

e-mail: veyseldag@akdeniz.edu.tr

ORCID: 0000-0002-2111-7756

Geliş tarihi / Received

06.03.2017

Düzeltme tarihi / Received in revised form 14.08.2017

Elektronik erişim / Online available

05.09.2017

\section{Anahtar kelimeler:}

Koruma alanı

Çevre sorunu

Özel çevre koruma bölgesi

Pamukkale

Denizli

Keywords:

Protected area

Environmental problems

Specially protection area

Pamukkale

Denizli

\begin{abstract}
Özet
Kentleşme, birçok kaynak üzerinde olduğu gibi korunan alanlarda da çeşitli etkilere yol açabilmektedir. Bu etkiler korunan alanlar çevresindeki kullanımlara bağlı olarak farklılık gösterebilir. Hızlı kentleşmeye bağlı olarak Denizli kent merkezine yaklaşık 20 km uzaklıkta bulunan Pamukkale Özel Çevre Koruma Bölgesi (ÖÇKB)'nin alan içerisindeki ya da çevresindeki kullanımlardan kaynaklı çeşitli çevre sorunlarından olumsuz etkilendiği düşünülmektedir. Bu araştırmanın amacı ulusal ve uluslararası boyutta önem taşıyan Pamukkale ÖÇKB'nde çevredeki alan kullanımları ile ziyaretçilerden kaynaklanan çevre sorunlarının belirlenmesidir. Bu amaçla Pamukkale ÖÇKB ve çevresi ile ilgili yapılan gözlem ve incelemelerin yanı sıra, alanı ziyaret eden yerli turistlere yönelik, standart formlar aracılığıyla, karşılık görüşme yolu ile yerinde anket (400 kişiye) uygulanmıştır. Elde edilen tüm verilerden yararlanılarak, çevre sorunlarının olumsuz etki var/yok şeklinde değerlendirildiği “Etkileşim Matrisi" oluşturulmuş, alanın koruma/kullanma dengesinin sağlanması temelinde, belirlenen çevre sorunlarının etkilerinin azaltılması veya sorunun kaynağında çözülmesine yönelik bazı öneriler geliştirilmiştir.
\end{abstract}

\begin{abstract}
Urbanization can lead to various effects on protected areas as well as on many sources. These effects may vary depending on the use of the area around. Due to rapid urbanization, Pamukkale Specially Protection Area (SPA), which is located about $20 \mathrm{~km}$ from Denizli city center, is thought to be adversely affected by some environmental problems. In this study, it is aimed to determine environmental problems arising from environmental use and problems arising from the pavilion in Pamukkale SPA which is important in national and international dimensions. For this purpose, on-site questionnaires (400 persons) have been applied to the local tourists visiting the area through standard forms, by means of interviews, as well as observations and examinations about Pamukkale SPA and its surroundings. Based on all the data obtained, "Interaction Matrix" was established in which the environmental problems were assessed as having / not having a negative effect. Based on the provision of the conservation / utilization balance of the area, some suggestions were made to reduce the effects of the determined environmental problems or solve them at the source of the problem.
\end{abstract}

\section{GiRiş}

Dünyada her alanda yaşanan değişimler, canlı ve cansız doğal kaynaklar üzerinde olumsuz etkilerin artmasına ve çevre sorunlarının ortaya çıkmasına neden olmaktadır. Zaman içerisinde insanın doğaya yapmış olduğu etkiler sonucu oluşan çevre sorunlarının ortadan kaldırılması veya etkilerinin azaltılması çok kolay olamayacağından, sorunların oluşmadan önlenmesi yönündeki çalışmaların yapılması önem taşımaktadır.

1983 tarihli Çevre Kanununda "çevre, canlıların yaşamları boyunca ilişkilerini sürdürdükleri ve karşılıklı olarak etkileşim içerisinde bulundukları, biyolojik, fiziksel, sosyal, ekonomik ve kültürel ortam olarak, çevre kirliliği ise çevrede meydana gelen ve canlıların sağlığını, çevresel değerleri ve ekolojik dengeyi bozabilecek her türlü olumsuz etki olarak" tanımlanmaktadır. Son yıllarda ortaya çıkış ve etkileri uluslararası boyut kazanan çevre sorunlarını birbirlerinden soyutlamak ve her bir sorunu ayrı ayrı ele alıp değerlendirmek sorununun çözümü için mümkün olmamaktadır. Bununla birlikte küresel çevre sorunlarının aslında tek tek ortaya çıkan çevre sorunlarının bir toplamı olarak ifade edilebildiği üzerinde durulmaktadır. Çevresel sorunların büyüklüğü, karmaşıklığı ve çok boyutluluğu karşısında, ulusal alanda yürütülen politikalar bu sorunların çözümünde tek başına yeterli görülmemiş, çevrenin korunması için uluslararası alanda sıkı bir işbirliğinin zorunluluğu kavranmıştır (Dunlap ve Jorgenson 2012; Güneş 2012).

Bu çalışmada ülkemizin en fazla ziyaret edilen ulusal ve uluslararası düzeyde doğal ve kültürel değerler ile çok 
yönlü koruma statülerine sahip olan, Pamukkale Özel Çevre Koruma Bölgesi (ÖÇKB) sınırları içerisinde ve çevresinde bulunan mevcut kullanımlar ile ziyaretçilerden kaynaklanan baskıların doğal yapı üzerindeki etkilerinin ortaya konulması amaçlanmıştır. Bu amaçla çalışma alanı ve yakın çevresinin doğal ve kültürel yapısının kapsamlı analizinden elde edilen veriler, ilgili kişi ve kurumlarla yapılan görüşmeler ve alanı ziyaret edenlere uygulanan anket sonuçları ile birlikte ele alınarak değerlendirilmiş, alanda koruma/kullanma dengesinin kurulmasına katkı sağlayacak bazı öneriler sunulmuştur.

\section{MATERYAL ve YÖNTEM}

\section{Materyal}

Araştırma alanı, Denizli il merkezinin $20 \mathrm{~km}$ kuzeybatısında bazı yerleşim yerlerini içine alan, Pamukkale ÖÇKB'dir (Şekil 1). Pamukkale ÖÇKB başlangıçta orman rejimine alınarak her türlü yapılaşma ve kaynakların yanlış kullanımından korunmak istenmiş ve Gayrimenkul Eski Eserler ve Anıtlar Yüksek Kurulu'nun (GEEAYK) 13.12.1980 tarih ve A-2587 sayılı kararı ile "ı. Derece Arkeolojik ve I. Derece Doğal Sit Alanı" ve 22.10.1990 tarih ve 90/1117 sayılı Bakanlar Kurulu Kararı ile 6656 ha'lık alan "Özel Çevre Koruma Bölgesi" olarak tespit ve ilan edilmiştir. Ayrıca 09.12.1988 tarih ve 485 no ile UNESCO'nun Dünya Kültürel ve Doğal Mirasının Korunması Sözleşmesi uyarınca 1988 yılında doğal ve kültürel değerleri nedeniyle Dünya Miras Listesi'ne alınmıştır. Ayrıca alan, Doğa Koruma ve Milli Parklar Genel Müdürlüğünün yapmış olduğu çalışmalar sonucunda "Sulak Alan" ilan edilmiştir (Çevre ve Şehircilik Bakanlığı 2014; Doğa Koruma ve Milli Parklar Genel Müdürlüğü 2014; UNESCO 2014).

Alanın doğal ve kültürel peyzaj özelliklerinin belirlenmesi amacıyla Denizli Büyükşehir Belediyesi ve Pamukkale Belediyesi'nden sağlanan plan, proje raporları ile diğer ilgili kurumlardan (il Gıda Tarım ve Hayvancılık, Kültür ve Turizm ile Çevre ve Şehircilik Müdürlükleri, Denizli Orman Bölge Müdürlügü, MTA) elde edilen yazılı ve sözlü bilgiler, haritalar (jeoloji, hidroloji, toprak, topografik haritalar), Devlet Meteoroloji iş̧leri Genel Müdürlüğü’nün Denizli iklim istasyonundan, Karayolları Genel Müdürlüğü ve TCDD ile DSi 21. Bölge Müdürlüğü'nden sağlanan verilerden yararlanılmıştır. Çevresel etkilerin belirlenmesi aşamasında, araştırma alanını etkileyen Denizli kent merkezi ve Pamukkale ilçesinde Çevre ve Şehircilik il Müdürlüğü tarafından yapılan çevre kirlilik ölçümleri ve araştırma konusu ile alana yönelik yapılmış çeşitli araştırmalardan da faydalanılmıştır.

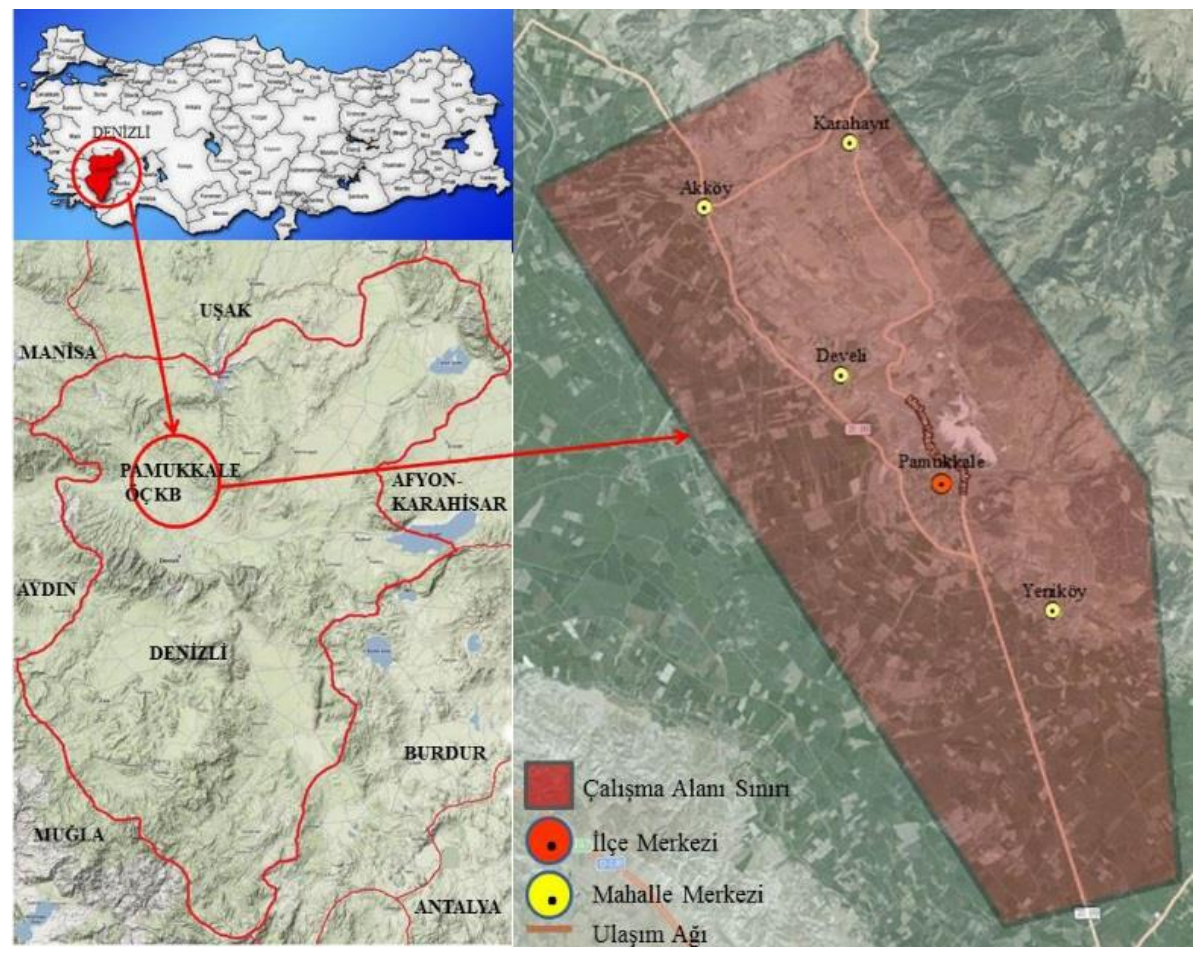

Şekil 1. Çalışma alanının coğrafi konumu ve sınırı. 
Araştırma alanında çevresel sorunların kaynağı ve etkilerinin saptanmasına yönelik ziyaretçilere yapılan anket, bireylerin sosyo-ekonomik yapısı ve Pamukkale ÖÇKB'deki çevre sorunları hakkındaki görüşlerinin saptanması olmak üzere 2 temelde yapılandırılmıştır. İki bölümden oluşan anketin I. bölümünde ziyaretçilerin demografik özellikleri (cinsiyet, medeni durum, yaş ve eğitim durumu), II. bölümünde ise Pamukkale ÖÇKB'de ziyaretçilerden kaynaklanan sorunların tespit edilmesine yönelik 5'li likert ölçeği (kesinlikle katılmıyorum, katılmıyorum, kararsızım, katılıyorum, kesinlikle katılıyorum) ve sıralama ölçütlü ifadeler yer almaktadır.

\section{Yöntem}

Pamukkale Özel Çevre Koruma Bölgesi'nde yürütülen araştırma, kapsam ve yönteminin belirlenmesinin ardından arazi ve ofis olmak üzere iki yönde ve dört aşamalı olarak yürütülmüştür. Araştırma yöntemi akış diyagramı Şekil 2'de sunulmuştur.

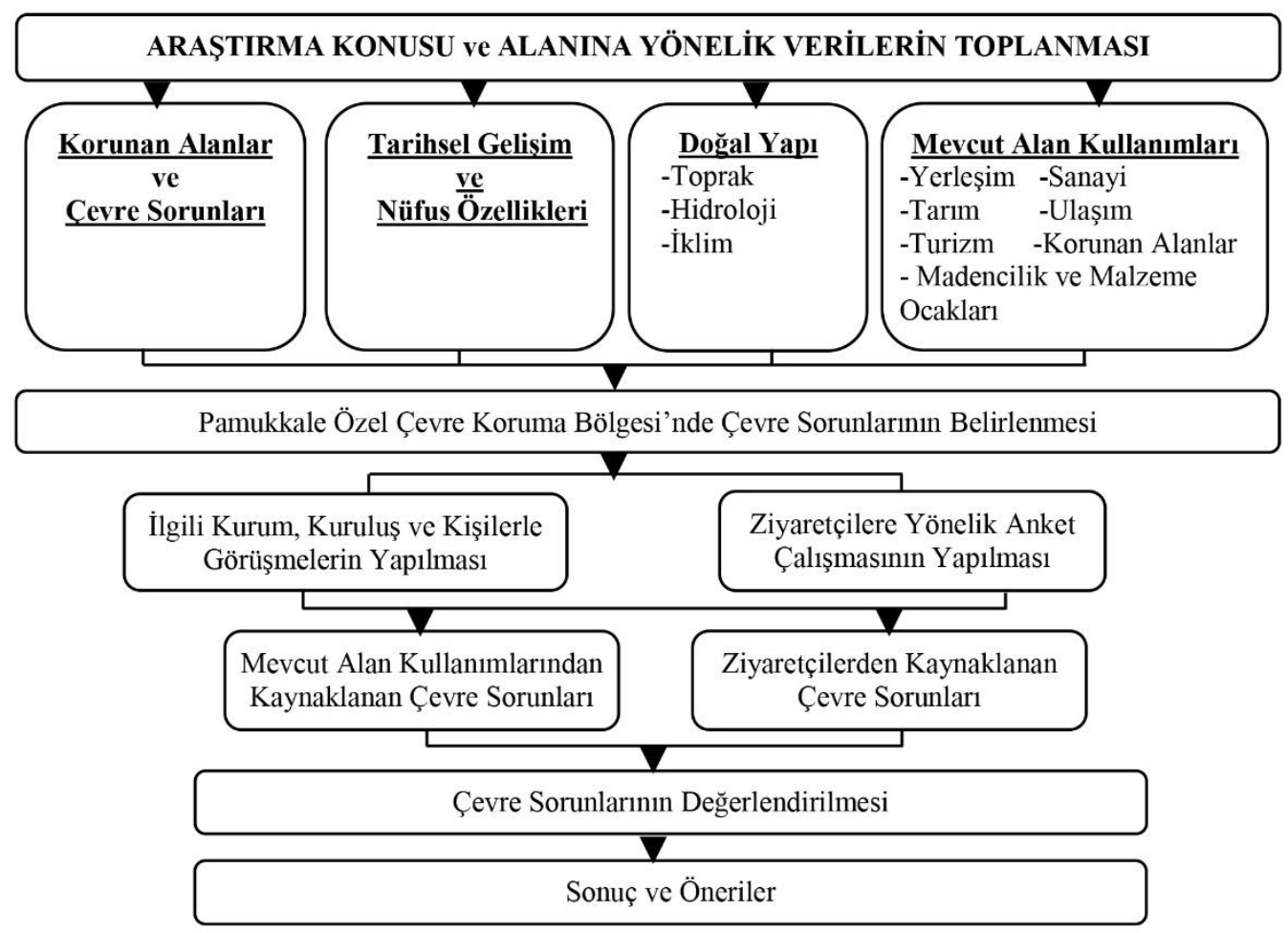

Şekil 2. Araştırma yöntemi akış diyagramı.

Araştırmanın ilk aşamasında literatür taraması ve Pamukkale ÖÇKB ile yakın çevresinin doğal ve kültürel özellikleri, alan kullanımları ve çevre sorunlarının değerlendirilmesinde kullanılan veriler elde edilmiştir. İkinci aşamada ilk aşamadan elde edilen bilgiler ışığında, araştırma alanında Nisan 2015-Nisan 2016 arasında, ÖÇKB içerisinde ve çevresinde, mevsimsel olarak gözlem ve incelemeler yapılarak Denizli kentinden; PamukkaleHierapolis Ören Yeri Doğu Kapısı/Traverten Bölgesi ve Antik Kent Bölgesi'nde ziyaretçi davranışları izlenerek, yöre halkı ile görüşülerek ve ziyaretçilere anket uygulanarak ziyaretçilerden kaynaklanan sorunlar belirlenmeye çalışılmıştır. Üçüncü aşamada, Denizli'de bulunan ilgili kurum ve kuruluş yetkilileri, Pamukkale
Hierapolis Ören Yeri (Traverten Bölgesi) yakın çevresinde yer alan işletme sahipleri ve yöre halkı ile görüşmeler yapılarak alan ve sorunları hakkında bilgi alınmıştır. Ayrıca araştırma alanında en etkin kullanım olan ziyaretçilerden kaynaklanan çevre sorunlarının belirlenmesi amacıyla ören yeri yaya girişinde alanı ziyaret eden yerli turistlere yönelik, standart formlar aracılığıyla, yerinde, karşılık görüşme yolu ile bir anket uygulanmıştır. Anket uygulanan kişiler, alanı yıl boyunca farklı dönemlerde ziyaret eden ziyaretçiler içerisinden, rastlantısal seçim ile oluşturulmuştur. Örnekleme büyüklüğünün saptanmasında Arkin ve Colton'un $\% 5$ hata payına göre 100.000'nin üzerindeki nüfus için öngördüğü en az 400 ziyaretçi sayısı temel alınmıştır (Pulido 1972). 
Anket formlarından elde edilen veriler kodlanarak bilgisayar ortamına aktarılmış olup, IBM SPSS 20 programında değerlendirilmiştir. Ziyaretçilerin cinsiyeti, medeni durumu, yaşı, eğitim düzeyi gibi temel değişkenler sınıflama ya da sıralama düzeyinde değişken olduklarından, bunlar arasındaki ilişkilerin araştırılmasında ki-kare $\left(\chi^{2}\right)$ uygunluk testi kullanılarak analizler yapılmıştır. Analizlerin güvenliğinin sağlanması amacıyla bazı değişkenlerde beklenen değerin 5'ten küçük olduğu hücre sayısı, toplam hücre sayısının \%20'sinden fazla olduğundan ki-kare değerlendirilmesi uygun görülmediğinden, "Ağırlıklandırma-Weight Cases" tekniği kullanılarak hücre değerleri $5^{\prime}$ in üzerine çıkarılmıştır. Veri analizlerinde değişkenlerin karşılaştırılmasını sağlayan çapraz çizelgeler kullanılmıştır. Son olarak elde edilen tüm verilerden yararlanılarak, çevre sorunlarının olumsuz etki var/yok şeklinde değerlendirildiği “Etkileşim Matrisi” oluşturulmuş, alanın koruma/kullanma dengesinin sağlanması temelinde, belirlenen çevre sorunlarının etkilerinin azaltılması veya sorunun kaynağında çözülmesine yönelik bazı öneriler geliştirilmiştir.

\section{BULGULAR ve TARTIŞMA}

\section{Tarihsel Gelişim ve Nüfus Özellikleri}

Denizli'deki ilk yerleşim, MÖ 5500 yılında, bugünkü Laodikeia Antik Kenti'nin bulunduğu yerde Lykos (Çürüksu) Vadisi sınırları içerisindeki Roas kentidir (Malay 1988, Şimşek 2007). Verimli ovası, uygun iklim koşulları ve önemli yolların kavşak noktasındaki bölgenin en büyük antik kenti ise Laodikeia'dır (Akçakoca Akça 2011). Bizans yönetiminde gerileyen Laodikeia, politik ve sosyoekonomik çöküntüler, doğal afetler ve istilalar gibi nedenlerden dolayı terk edilmiştir (Coşkun 2007). Denizli, Selçuklu dönemine kadar sürekli Bizanslılar ile Türkler arasında el değiştirmiştir (Akçakoca Akça 2011). Cumhuriyet'in ilk yıllarında verimli tarım arazilerinin bulunduğu Tavas-Acıpayam yönünde büyüyen kent, ulaşım ağlarının gelişimi ile çekim merkezi konumuna gelmiştir. Tarım ve hayvancılığın yanında dokumacılığın gelişmesi ile sanayi kuruluşları artmış, kırdan kente göç başlamıştır (Kodal 2004). Denizli'nin 1973 yılında Kalkınmada Öncelikli Yöreler (KÖY) kapsamına alınması sanayiyi geliştirmiş, 1976 yılındaki depremin ardından yeni konutların doğu ve güneye yayılması, batıda organize konut alanlarını oluşturmuş ve kentin çevre yerleşimler ile bütünleşmesini sağlamıştır (Savaş 2011).

Araştırma alanını doğrudan etkileyen merkez ve 1990 yılında ilçe olan Akköy'ün nüfus gelişimleri incelendiğinde (Çizelge 1) Akköy nüfusunda zaman zaman düşüş yaşandığı, ancak 2013 yılında Denizli'nin Büyükşehir ilan edilmesi ile birlikte merkez ilçe nüfusun \%53.56 oranında azaldığı, Akköy (Pamukkale) ilçe nüfusunun ise yaklaşık 57 kat arttığı görülmektedir. Bu durum kentin gelişme yönünü ortaya koyduğu gibi Pamukkale ÖÇKB üzerinde ciddi bir nüfus baskısının oluşabileceğini de düşündürmektedir. 2016 yılı itibariyle Denizli nüfusunun yaklaşık \%62'sinin alanı etkileyebileceği düşünülmektedir.

Çizelge 1. Araştırma Alanını Etkileyen Nüfusun Yıllara Göre Dağıımı (TÜiK 2016).

\begin{tabular}{|c|c|c|c|c|c|c|c|c|c|c|c|}
\hline & 2000 & 2007 & 2008 & 2009 & 2010 & 2011 & 2012 & 2013 & 2014 & 2015 & 2016 \\
\hline Merkez & 400.719 & 494.961 & 508.870 & 517.911 & 527.617 & 540.989 & 554.424 & 262.825 & 271.942 & 280.341 & 287.852 \\
\hline Akköy & 6.437 & 5.225 & 5.609 & 5.518 & 5.492 & 5.466 & 5.392 & 311.496 & 320.142 & 331.000 & 337.444 \\
\hline
\end{tabular}

\section{Peyzajın Doğal Kaynak Değerleri}

Yüzey şekilleri bakımından dalgalı bir yapıya sahip olan Denizli'de merkez ilçenin deniz seviyesinden yüksekliği 354 m iken, Pamukkale ilçe merkezinin rakımı 235 m’dir (Denizli Valiliği 2015). Denizli yerleşim alanı kuzeyden ve güneyden faylarla sınırlı olan çöküntü alanı üzerindedir. Bölgede yaşanan depremler fayların aktif olduğunu göstermektedir (Kumsar ve ark. 2004). Çürüksu grabeninin oluşumu sonucunda gelişen hidrotermal yapı içerisinde faylar boyunca yüzeye ulaşan yüksek verdili, kalsiyum karbonatlı $\left(\mathrm{CaCO}_{3}\right)$, sülfatlı $\left(\mathrm{SO}_{4}\right)$ termal sular, yaklaşık $10 \mathrm{~km}^{2}$ yüzey alanına ve $100 \mathrm{~m}$ kalınlığa sahip travertenleri oluşturmaktadır (Güner ve Elhatip 1999).

Pamukkale ÖÇKB yakınında bulunan akarsular Büyük Menderes ve Çürüksu'dur. Denizli için önem taşıyan Büyük Menderes (548 km), Denizli il içerisinde (194 km'lik bölümü) Işıklı Gölü’nden beslenerek, Çivril, Çal ve Baklan 
Ovalarından geçer, Sarayköy'de Çürüksu Çayı ile birleşir ve Aydın sınırına girer. Suyu çok kireçli olan Çürüksu (101 km), Araplar Çayı, Subaşı Deresi, Sazıı Dere, Karakııık Çayı, Karaçay, Honaz Çayı ve Gökpınar Suyu ile beslenir. Pamukkale'de antik dönemden itibaren termal suların tarımda sulama ve turizmde kaplıca suyu olarak kullanımı insanla, travertenleri oluşturması ise doğayla ilişkisini ortaya koymaktadır (Doğaner 1996).

Denizli Meteoroloji îl Müdürlüğü (2015)’nün (1960-2014) iklim verilerine göre, ortalama sıcaklık Denizli' de $16.2{ }^{\circ} \mathrm{C}$, Pamukkale'de (2007-2010) ise $11.7{ }^{\circ} \mathrm{C}^{\prime}$ dir. Ortalama en düşük sıcaklık sırasıyla $2.2^{\circ} \mathrm{C}$ ve $2.3^{\circ} \mathrm{C}$, ortalama en yüksek sıcaklık ise $22.4{ }^{\circ} \mathrm{C}$ ve $23.6{ }^{\circ} \mathrm{C}$ 'dir. Akdeniz ile karasal iklimin görüldüğü Denizli'de ortalama toplam yağış miktarı 567.9 mm'dir. En yüksek ortalama yağış (92.5 mm) Aralık ayında, en düşük yağış ise $(8.3 \mathrm{~mm})$ Ağustos ayındadır. Her iki merkezde de ortalama bağı nemin en yüksek olduğu ay Aralık iken, bu değer Denizli'de \%73.4, Pamukkale'de ise \%73.1'dir. En düşük bağıl nem Denizli'de Şubat (\%3), Pamukkale'de Mayıs (\%8) ayında ölçülmüştür. Ortalama rüzgar hızı Denizli'de $1.2 \mathrm{~m} / \mathrm{sn}$, Pamukkale'de $2.1 \mathrm{~m} / \mathrm{sn}$ ve en kuvvetli rüzgar yönü ise güneybatıdır.

Pamukkale ÖÇKB Akdeniz Fitocoğrafik Bölgesi sınırları içerisinde bulunmaktadır. Bölgede yürütülen Biyolojik Çeşitliliğin Tespiti Projesinde Pamukkale ÖÇKB içerisinde yayılış gösteren türlerin 29 tanesinin endemik (\%5.6) olduğu belirtilirken, IUCN sınıflandırmasına göre 3 adet $L R(n t), 2$ adet VU, 20 adet LR(LC), 1 adet DD, 2 adet EN ve 1 adet LR(cd) kategorisinde yer aldığı, 4 adet endemik bitki türünün herhangi bir kategori içinde yer almadığı tespit edilmiştir. Pamukkale ÖçKB içerisinde yerleşim alanlarının yayılmasıyla bitki örtüsünün yok olması, ulaşım ağlarının yaşam alanlarını parçalaması ve buralardan yayılan toz, zehirli gazlar vb. maddeler yaban hayatında ölümlere neden olmaktadır (Şahin ve ark. 2010).

\section{Mevcut Alan Kullanımları}

Yerleşim: Araştırma alanı içerisinde 1'i ilçe merkezi olmak üzere toplam 5 (Pamukkale, Karahayıt, Akköy, Yeniköy, Develi) mahalle bulunmaktadır. Yerleşimler genellikle ova arazisi üzerinde konut ve turizm yapıları şeklinde görülmektedir. Son yıllarda koruma alanı çevresinde artan yerleşimlerin travertenlere uzaklığı yaklaşık 25 m'ye kadar inmiştir. Yerleşimlerin artışı travertenlerin yapısını bozabilecek hava, su ve toprak kirliliği gibi çeşitli çevre sorunlarını da artırmaktadır. Çalışma alanını etkileyen Eldenizli, Irlıganlı, Küçükdere, Salihağa, Yukarışamlı, Çeltikçi, Karakova, Goncalı ve Korucuk mahallelerinin gelişme ve büyüme potansiyelleri yüksektir. Arazi gözlemlerinde yeni yapılan konutların yanında turizm tesislerinin de tarım alanlarına doğru ilerlediği tespit edilmiştir.

Sanayi: İhracata önem veren Denizli sanayisi başta tekstil olmak üzere birçok dalda önemli paya sahiptir. Sanayi altyapısı gelişmiş olan kentte 1 adet Serbest Bölge, 1 adet Teknokent'in yanı sıra, 4 adet tamamlanmış (Denizli Organize Sanayi Bölgesi, Denizli Çardak Özdemir Sabancı Organize Sanayi Bölgesi, Denizli Deri ihtisas Organize Sanayi Bölgesi, Organize Sanayi Bölgesi), 1 adet inşaa halinde olmak üzere toplam 5 adet organize sanayi bölgesi bulunmaktadır. Denizli Organize Sanayi Bölgesi'ndeki 119 tekstil sektörü tesisinde yaklaşık 25.000 kişi istihdam edilmektedir (DOSB 2013; GEKA 2014; Bilim, Sanayi ve Teknoloji Bakanlı̆̆ı 2015).

Tarım: Denizli arazi dağıımının \%32'si tarım arazisi olmasına rağmen, sektörel dağılım içerisinde tarımın payı (\%1.39) oldukça azdır. 2013 yılı için tarla bitkileri alansal olarak en büyük paya (\%81.7) sahip olup, bunu bağ alanları (\%11.3), meyve alanları (\%7.5) ve sebze alanları (\%3.3) izlemektedir. Aynı dönemde 116.62 da alanda çiçek soğanı ve diğer süs bitkilerinin üretimi yapılmıştır (Denizli ill Gıda Tarım ve Hayvancılık Müdürlüğü 2015).

Ulaşım: Ankara-Afyonkarahisar-i̇zmir ve Antalya-Bursaİstanbul karayollarının kesişim noktasında bulunan Denizli'de 826 km'lik farklı özelliklerdeki karayolları ile ulaşım sağlanmaktadır. Ayrıca $315 \mathrm{~km}$ olacağı öngörülen, Burdur-Denizli-Aydın otoyolu proje aşamasındadır. Pamukkale ÖÇKB'nin güneyindeki demiryolu ilin IspartaAydın-izmir ile bağlantısını sağlamaktadır. Denizli-Antalya bağlantısını sağlayacak hızı tren hattının proje aşamasında olduğu, Denizli-i̇zmir arasında yeni bir demiryolu bağlantısının da gündemde olduğu belirtilmiştir (TCDD 2016). 
Korunan alanlar: Denizli'de 1 adet milli park (Honaz Dağı Milli Parkı-9.429 ha), 2 adet yaban hayatı geliştirme sahası (Denizli Çivril Akdağ YHGS ve Denizli Çardak Beylerli YHGS11553 ha), 1 adet tabiat parkı (Akdağ Tabiat Parkı-14 692 ha) ve 1 adet özel çevre koruma bölgesi (Pamukkale ÖÇKB-6 656 ha) bulunmaktadır. Ayrıca 194 adet arkeolojik, 1 adet kentsel, 8 adet arkeolojik ve doğal, 1 adet kentsel ve doğal sit olmak üzere toplam 204 adet sit alanı bulunmaktadır (Kültür Varlıkları ve Müzeler Genel Müdürlüğü 2015).

Turizm: Denizli' de Turizm İşletme Belgeli 6272 yataklı 26 tesis, Belediye Belgeli 6879 yataklı 78 tesis ve 5157 yataklı 129 pansiyon ile turizme hizmet sunan toplam 18 308 yataklı 233 tesis bulunmaktadır. Turizm belgeli, toplam 3401 yatak kapasiteli 15 adet tesisin inşaatı devam etmektedir. Ayrıca turizm belgesiz 2 adet Kür Merkezi, 1 adet Fizik Tedavi ve Rehabilitasyon Merkezi ve 2 adet Termal Otel olmak üzere 5 adet turizm yatırımı da bulunmaktadır. İlin yatak kapasitesinin 2015 yılı itibariyle yılda 5 milyon turisti ağırlayabileceği belirtilmektedir (Denizli il Kültür ve Turizm Müdürlüğü 2015).

Madencilik ve malzeme ocakları: Denizli doğal özellikleri açısından traverten ve mermer başta olmak üzere doğal taş sektöründe de önemli bir yere sahiptir. Dünyanın çeşitli ülkelerine ihracat yapıldığından, madencilik ve buna bağlı gelişen sektörler il ekonomisine katkı sağlamaktadır. Çalışma alanı içerisinde bulunan sarı traverten ocağı ile Kocabaş Mahallesi'ndeki mermer ve traverten ocakları çevreyi olumsuz etkileyebilmektedir. Arazi çalışmaları sırasında Akköy yakınlarındaki traverten ocağından kaynaklanan tozların ÖÇKB içerisindeki ve yakın çevresindeki tarım, orman ve yerleşim alanlarını, Pamukkale traverten sahasını, su yüzeylerini ve görsel peyzaj unsurlarını etkilediği gözlenmiştir.

\section{Mevcut Alan Kullanımlarından Kaynaklanan Çevre Sorunları}

Hava Kirliliği: Hava kirliği canlı ve cansız çevre üzerinde doğrudan veya dolaylı etkilidir. Bu etkilerin azaltılması için Dünya Sağlık Örgütü-WHO (PM $\left.{ }_{10}: 50 \mu \mathrm{gm}^{3}, \mathrm{SO}_{2}: 20 \mu \mathrm{gm}^{3}\right)$, Avrupa Birliği-AB ( $\left.\mathrm{PM}_{10}: 50 \mu \mathrm{gm}^{3}, \mathrm{SO}_{2}: 125 \mu^{3} \mathrm{gm}^{3}\right)$ ve ülkemiz $\left(\mathrm{PM}_{10}: 90 \mu \mathrm{gm}^{3}, \mathrm{SO}_{2}: 225 \mu \mathrm{gm}^{3}\right)$ günlük sınır değerleri aşılmamalıdır. Denizli kent merkezinde Çevre ve
Şehircilik Bakanlığı'na bağlı, çalışma alanına en yakın Denizli-2 (Bayramyeri) hava kirliliği ölçüm istasyonu verilerine göre, 2007-2011 döneminde $\mathrm{PM}_{10}$ oranı WHO, $A B$ ve ülkemiz sınır değerlerinin çok üzerindedir. $\mathrm{SO}_{2}$ değerleri ise 2007 ve 2008 yılları ile eksik ölçümlerin bulunduğu bazı yıllarda (2013-2016 arası) eşik sınırı aşmıştır. Günümüzde doğalgaz kullanımının yaygınlaşması ile değerlerde düşüşler görülse de nüfus artışı, motorlu araç sayısındaki artış (motorlu araç sayısı 2007'de 237622 adet, 2016'da 374219 adet) ve sanayi gelişmeleri hava kalitesini olumsuz etkilemektedir (TÜiK 2017)

Su Kirliliği: Sanayileşme ve kentleşme, altyapı ve arıtma tesislerinin yetersizliği, tarımda bilinçsiz ilaç ve gübre kullanımı gibi nedenler yerüstü ve yeraltı su kaynaklarını kirletmektedir. 376738 ha tarım arazisine sahip olan Denizli'de 2013-2015 yıllarında ortalama 80000 ton, dekar başına ise $20 \mathrm{~kg}$ gübre kullanılmıştır. Pamukkale' de ise 28836 ha tarım arazisinde yaklaşık 6123.3 ton gübrenin kullanıldığı $(21.23 \mathrm{~kg} / \mathrm{da})$ tahmin edilmektedir. Ülkemizde 2011 yılında kullanılan gübre miktarı 38.43 kg/da'dır (TÜiK 2013). Denizli ve Pamukkale'de kullanılan gübre miktarı bu değerden az olsa da toprak özellikleri, jeolojik yapı, sulama suyu kalitesi gibi faktörler ile etkinliği değişebilmektedir.

Toprak kirliliği: Çalışma alanının büyük bir kısmını oluşturan Çürüksu Ovası, Çürüksu Nehri, DSi sulama kanalları ve travertenlerden boşalan ve aşırı miktarda kalsiyum karbonat $\left(\mathrm{CaCO}_{3}\right)$ içeren sular ile sulanmaktadır. Sulama suyu kalitesinin kötü olması ve verimi arttırmak için aşırı gübre kullanımı, toprak tuzluluğunun artmasına ve taban suyunun kirlenmesine yol açabilmektedir. Kimyasal gübreler verimi arttırırken, toprağın fiziksel, kimyasal ve biyolojik özelliklerini olumsuz etkileyebilmektedir. Ek olarak inşaat kolaylığı, şehir merkezine yakınlık ve kentin gelişme potansiyeli yönünde bulunmasından dolayı tarım alanları yerleşim, turizm ve ulaşım gibi alan kullanımları tarafından işgal edilmektedir.

Gürültü kirliliği: Çalışma alanında doğal yaşamı etkileyebilecek gürültü kaynağı olan Sarayköy-Aydın karayolundan geçen araç sayısına göre eşdeğer gürültü düzeyleri Mansuroğlu (1999)’ndan yararlanılarak 64.13 
dBA olarak hesaplanmıştır. Bu düzey, ülkemiz karayolu çevresel gürültü sınır değerlerinden, ticari yapılar ile gürültüye hassas kullanımların birlikte bulunduğu alanlardan konutların yoğun olarak bulunduğu alanlar için belirlenen kabul edilebilir gündüz $(68 \mathrm{dBA})$ gürültü düzeyinin altında iken, akşam ( $63 \mathrm{dBA}$ ) ve gece $(58 \mathrm{dBA})$ düzeylerinin ise üstündedir. Proje aşamasında olan otoyollar dikkate alındığında, gelecekte gürültü düzeyinin artacağı tahmin edilmektedir.

\section{Alan Kullanımlarının Doğal Peyzaj Üzerindeki Etkileri}

Çalışmanın bu aşamasında, çalışma alanı sınırları içerisinde ve çevresinde bulunan yerleşim, ulaşım, su kullanımı, atık, madencilik, sanayi, tarım ve turizm gibi kullanımlar ile doğal yapı (iklim ve hava, toprak, su, bitki örtüsü, yaban hayatı ve peyzaj görünümü) arasındaki etkileşimi ortaya koymak amacıyla bir "Etkileşim Matrisi" oluşturulmuştur (Çizelge 2). Bu matrisin oluşturulmasında yukarıda ilgili bölümlerde açıklanan araştırma alanının doğal peyzaj özellikleri ve mevcut alan kullanımlarından ve arazide yapılan gözlemlerden yararlanılmıştır. Ortaya koyulan çevresel etkiler olumsuz etki var (+), olumsuz etki yok (-) şeklinde değerlendirilmiştir. Böylece ortaya çıkan çevresel etkilerin alandaki faaliyetlerin yanında çevredeki kullanımlarla etkileşimi de saptanarak, çevresel etkilerin kaynağı belirlenmiştir.

Ülkemizde korunan alanların çevresinde tampon alanların oluşturulmaması koruma çalışmalarının etkinliğine zarar vermektedir. Bu çalışmada Pamukkale ÖÇKB'nin Denizli kent merkezinde yaşanan çevre sorunları başta olmak üzere, çevredeki sanayi tesisleri ve ulaşım ağlarından olumsuz etkilendiği sonucuna varılmıştır. Buna benzer şekilde, değişik korunan alanlarda çevredeki sorunların korunan alanlar üzerinde etkili olduğu belirtilmektedir. Sütgibi (2008) Büyük Menderes Deltası'nın nehrin kaynağından denize döküldüğü yere kadar atık su deşarjları, endüstriyel faaliyetler, tarımsal faaliyetler ve jeotermal kaynaklı doğal salınımlar nedeniyle kirlendiğini, havza genelinde sulu tarımın yapıldığını ve özellikle drenajın yetersiz olduğu yerlerde yüksek $\mathrm{pH}$, tuzluluk, sodyumluluk ve yüksek taban suyu gibi sorunların olduğunu tespit etmiştir. Bahadır (2013) Kovada Gölü Milli Parkı'nda tarım alanlarının amaç dışı kullanımı, aşırı avlanma, orman yangını riski ve taşıma kapasitenin zorlanması gibi etkenleri milli parkın gelecekteki en büyük çevresel sorunları olarak tespit etmiştir. Castellani ve Sala (2012) Oltrepo Mantovana (italya) koruma alanında yoğun trafikten kaynaklanan, gürültü ve yüksek derecede hava kirliliği saptamışlardır.

\section{Ziyaretçilerden Kaynaklanan Çevre Sorunları}

Pamukkale-Hierapolis Ören Yeri Doğu Kapısı (Traverten Bölgesi) girişinde, yüz yüze görüşme yöntemi ile yapılan anket çalışması, alanı ziyaret eden yerli ziyaretçilere/turistlere rastlantısal olarak uygulanmıştır. Temmuz 2015 ve Ekim 2015 tarihleri arasında uygulanan anketlerden 400 tanesinin değerlendirmeye uygun olduğu tespit edilmiştir. Anket bireylerin sosyo-ekonomik yapısı ve Pamukkale ÖÇKB'deki çevre sorunları hakkındaki görüşlerinin saptanması olmak üzere 2 temelde yapılandırılmıştır.

Ankete katılanların $\% 66$ 'sı erkek, $\% 34$ 'ü kadın olup, bunların \%43.5'i evli, \%55.7'si bekar ve \%0.8' $i$ ise boşanmıştır. Araştırmaya katılanların \%43'ünün 18-24 yaş aralığında olmasından da anlaşılacağı üzere ankete katılanların büyük bir kısmı (\%35.7) öğrencidir. Eğitim durumuna göre lise ve üniversite mezunları çoğunluğu oluşturmaktadır (\%37). Ankete katılanlar kullanıcı sayısının fazla olmasına bağı alanda görülen sorunları çöpler (\%31.7), su kirliliği (\%26.3), travertenlerin kararması (\%22), kullanım alanlarının yetersizliği $(\% 18,5)$ şeklinde sıralamıştır. Bazı ziyaretçiler, alandaki tarihsel öğelerin de aşırı kalabalıktan zarar görebileceğini ifade etmişlerdir. 
Çizelge 2. Alan kullanımları ile doğal yapı arasındaki etkileşim matrisi.

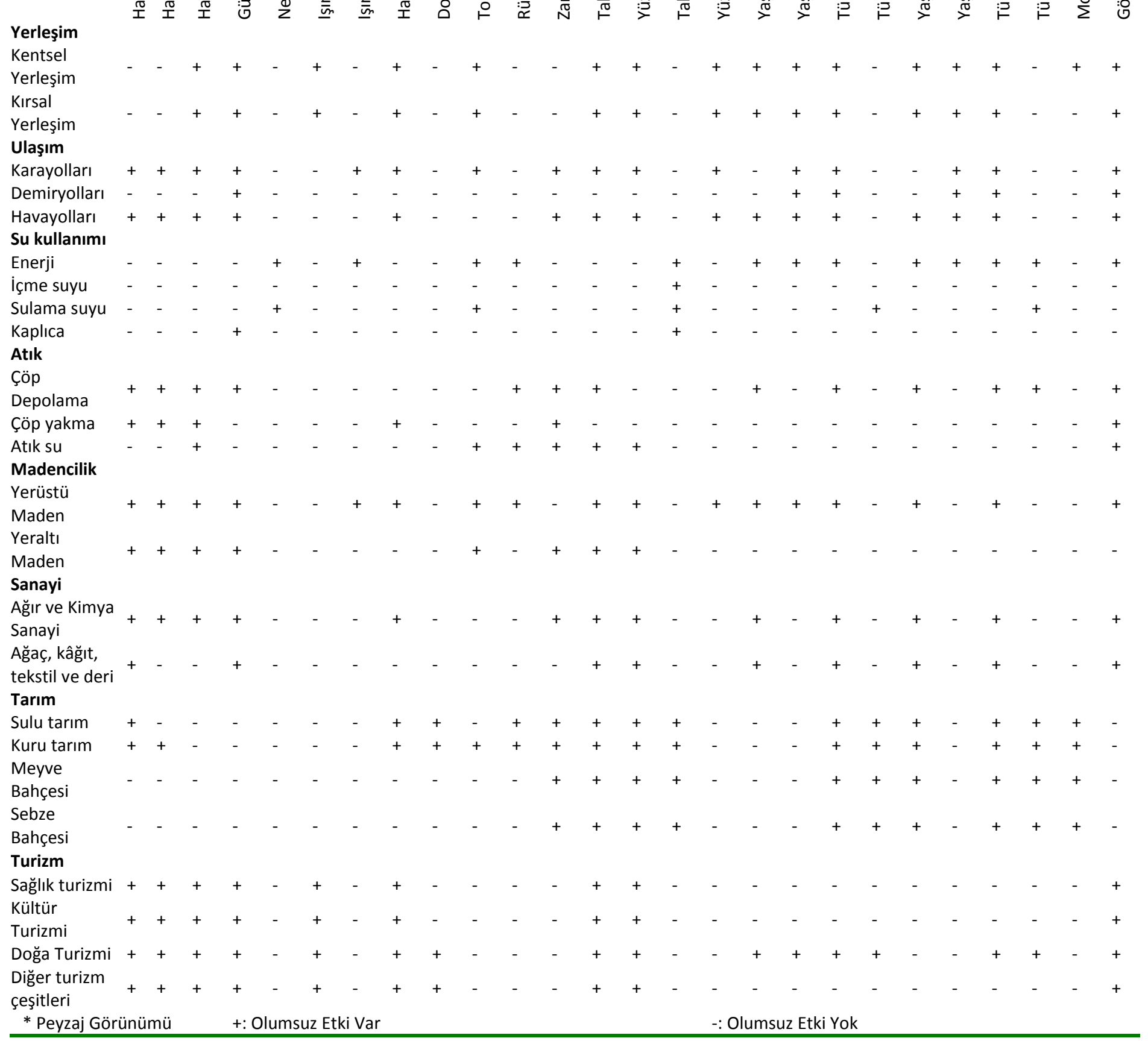


Araştırmaya katılanların sosyo-ekonomik durumları ile ankete verdikleri yanıtlar arasındaki ilişki incelendiğinde (Çizelge 3) travertenler üzerinde gezinmek travertenlere zararlıdır, kalabalıktan dolayı alandaki doğal, kültürel ve tarihsel öğelerin zarar görebileceğine inanıyorum, kalabalıktan dolayı travertenlerin yapısının daha çabuk bozulacağına inanıyorum, travertenlerdeki kararmaların ziyaretçi yoğunluğundan kaynaklandığını düşünüyorum ifadelerine ziyaretçilerin çoğunlukla katılıyorum ve kesinlikle katılıyorum şeklinde yanıt verdikleri ve verilen yanıtlarda istatistiksel olarak anlamlı farklılıklar olduğu görülmektedir. Ancak travertenlerdeki kararmaların ziyaretçi yoğunluğundan kaynaklandığını düşünüyorum ifadesine ortaokul $(\chi 2=1.830, p=0.767)$ ve lisansüstü $(\chi 2=$ 9.143, $p=0.058$ ) eğitim düzeylerindeki ziyaretçilerin vermiş oldukları yanıtlara göre kararsız ziyaretçilerin fazla olduğu görülse de bunun istatistiksel olarak anlamlı bir fark teşkil etmediği anlaşılmaktadır.

2000 yılından günümüze kadar yılda ortalama 1.5 milyon son yıllarda da 2 milyona yaklaşan yıllık ziyaretçi sayısı ile ulusal ve uluslararası düzeyde önemli turizm bölgelerimizden biri olan Pamukkale'de çevre kullanımların yanı sıra ziyaretçilerden de kaynaklanan bazı sorunlar yukarıda açıklanmıştır. Dünya'da ve ülkemizde korunan alanların rekreasyon ve ziyaret amaçlı kullanımının alan üzerinde çeşitli etkiler oluşturabileceği bilinmektedir. Lantsova ve ark. (2005) Ivankovo Rezerv Alanı (Moskova, Rusya)'nda rekreasyonel kullanımlara bağlı olarak ortaya çıkan kirletici madde miktarındaki artıştan dolayı, deniz suyu kirliliğinin önüne geçilmesi amacıyla, bölgede yapılacak rekreasyonel faaliyetlerin sınıflandırılması gerektiğini ve bu sınıflandırmayla her bir faaliyet için yapılacak zonlama çalışmasıyla alandaki etkinin derecesinin azaltılabileceğini belirtmişlerdir. Ahmad ve ark. (2013) Langkawi Adaları (Malezya)'nda doğal alanlara turist akışının uzun vadede doğal kaynaklara zarar verebileceğini ve bunun sonucu olarak erozyon artışı ile birlikte flora ve faunanın zarar görebileceğini belirtmişlerdir. Bunun yanı sıra bölgede toprak, hava, su ve gürültü kirliliğinde artış olduğu vurgulanarak, özellikle yerel ve bölgesel yöneticiler ile turizmcilerin birlikte çalışarak, bölgenin fiziksel ve sosyoekonomik parametreleri de temel alınarak taşıma kapasitesi hesaplamalarının yapılması gerektiğini önermişlerdir.

\section{SONUÇ ve ÖNERILER}

Denizli'de sanayi, kentsel gelişim ve turizm bölgeleri oluşturulması ile bunların yayılmasının sınırlandırılmaması sonucu Pamukkale ÖÇKB'nde mevcut alan kullanımlarından kaynaklanan hava, toprak, su ve gürültü kirliliği, bitki ve hayvan yaşam alanlarının zarar görmesi ile peyzaj görünümünün değişimi gibi sorunlar görülmektedir. Araştırma alanı çevresinde yaşanan bu değişimin, hava ve su kirliliğinden etkilenme riski yüksek olan travertenler üzerinde etkili olması kaçınılmazdır. Denizli'de sanayi tesislerinin artması ve sanayi dallarının çeşitlenmesi, turizm gelişmeleri ve artan kentleşme araştırma alanını doğrudan etkilemeye başlamıştır. Pamukkale ÖÇKB sınırları içerisinde büyük bir sanayi sitesi bulunmamasına rağmen, alan içerisinde küçük çaplı bazı üretim tesisleri (kilit parke taş, taş işleme tesisi vb.) bulunmaktadır. Toz, partikül madde ve gürültünün ortaya çıkmasına neden olan bu tesislerin, tarım alanları, travertenler, tarihi alanlar, yerleşim alanları ve orman alanları üzerinde olumsuz etkilerinin olabileceğ düşünülmektedir.

Pamukkale ÖÇKB'nin Denizli Organize Sanayi Bölgesi, Deri İhtisas Organize Sanayi Bölgesi ve Denizli Çimento Fabrikasının etki alanı içerisinde olabileceği düşünülmektedir. Çalışma alanına en yakın $(32 \mathrm{~km})$ ve kimyasal, plastik-kauçuk, metal gibi faaliyetlerde üretim yapan tesis sayısının (32 adet) az olmadığı Denizlı Organize Sanayi Bölgesi'nin toprak, su, hava, bitki örtüsü, yaban hayatı gibi doğal faktörler üzerinde etki oluşturabileceği dikkat çekmektedir. Ayrıca mevcut kullanımlardan kaynaklanan hava kirliliği, kentte zaman zaman eşik sınırı aşmaktadır. Kentin I. derecede öncelikli sorunu olarak görülen hava kirliliği, travertenlerin kirlenmesine de neden olan önemli faktörlerdendir. Pamukkale ÖÇKB içerisinde büyük orman bulunmaması, sanayi ve yerleşimin bu bölgeye doğru gelişmesi, doğal ve kültürel öğelerin zarar görme olasılığını artırmaktadır. Bu nedenle çalışma alanı içerisinde veya sınırında zonlamaya gidilmesi bu alanların daha az etkilenmesi açısından önemlidir. 
Çizelge 3 Pamukkale/Hierapolis Ören Yeri ziyaretçilerinin alan hakkındaki görüşleri

\begin{tabular}{|c|c|c|c|c|c|c|c|}
\hline & & Kesinlikle katılmıyorum Katılmıyorum & Kararsızım & Katılıyorum & Kesinlikle katılıyorum & Chi-Square & $P$ Value \\
\hline \multicolumn{8}{|c|}{ Travertenler üzerinde gezinmek travertenlere zararlıdır } \\
\hline \multirow[t]{2}{*}{ Cinsiyet } & Kadın $(n=136)$ & 19.1 & 19.1 & 25.0 & 28.7 & 16.574 & 0.002 \\
\hline & Erkek $(n=264)$ & 13.6 & 20.1 & 28.8 & 24.6 & 25.053 & $<0.001$ \\
\hline Medeni & Evli (n=174) & 13.1 & 20.0 & 30.9 & 29.1 & 36.857 & $<0.001$ \\
\hline \multirow[t]{2}{*}{ Durum } & Bekâr (n=223) & 17.6 & 19.8 & 25.2 & 22.5 & 7.324 & 0.120 \\
\hline & Boşanmış (n=3) & 0.0 & 0.0 & 0.0 & 100.0 & - & - \\
\hline \multirow[t]{6}{*}{ Yaş } & $18-24$ Yaş $(n=172)$ & 19.2 & 19.2 & 24.4 & 18.6 & 2.128 & 0.712 \\
\hline & $25-34$ Yaş $(n=111)$ & 15.3 & 24.3 & 26.1 & 27.9 & 18.234 & 0.001 \\
\hline & 35-44 Yaş (n=59) & 15.3 & 18.6 & 30.5 & 30.5 & 13.797 & 0.008 \\
\hline & 45-54 Yaş $(n=36)$ & 5.6 & 11.1 & 44.4 & 33.3 & 22.889 & $<0.001$ \\
\hline & 55-64 Yaş $(n=18)$ & 0.0 & 22.2 & 22.2 & 50.0 & 7.333 & 0.062 \\
\hline & +65 Yaş $(n=4)$ & 25.0 & 0.0 & 25.0 & 50.0 & 0.500 & 0.779 \\
\hline \multirow[t]{6}{*}{ Eğitim Düzeyi } & illkokul (n=15) & 6.7 & 13.3 & 26.7 & 53.3 & 7.667 & 0.053 \\
\hline & Ortaokul (n=47) & 21.3 & 19.1 & 25.5 & 27.7 & 6.511 & 0.164 \\
\hline & Lise $(n=148)$ & 14.9 & 14.2 & 27.0 & 22.3 & 8.689 & 0.069 \\
\hline & Yüksekokul (n=14) & 7.1 & 35.7 & 50.0 & 7.1 & 7.714 & 0.052 \\
\hline & Lisans (n=148) & 14.9 & 23.6 & 29.1 & 23.6 & 19.294 & 0.001 \\
\hline & Lisansüstü (n=28) & 10.7 & 25.0 & 14.3 & 26.0 & 10.571 & 0.014 \\
\hline \multirow{3}{*}{ Cinsiyet } & & Kalabalıktan dolayı alandaki doğal, kültü & el ve tarihsel & elerin zarar gc & bileceğine inanıyorum & & \\
\hline & Kadın $(n=136)$ & 14.7 & 11.8 & 35.3 & 37.5 & 68.485 & $<0.001$ \\
\hline & Erkek $(n=264)$ & 19.7 & 8.3 & 33.0 & 30.3 & 70.962 & $<0.001$ \\
\hline Medeni & Evli (n=174) & 29.7 & 7.4 & 29.1 & 23.4 & 89.486 & $<0.001$ \\
\hline \multirow[t]{2}{*}{ Durum } & Bekâr (n=223) & 25.2 & 10.8 & 28.8 & 20.3 & 51.919 & $<0.001$ \\
\hline & Boşanmış $(n=3)$ & 66.7 & 0.0 & 33.3 & 0.0 & - & - \\
\hline \multirow[t]{6}{*}{ Yaş } & $18-24$ Yaş (n=172) & 19.8 & 14.5 & 34.9 & 23.3 & 35.849 & $<0.001$ \\
\hline & $25-34$ Yaş $(n=111)$ & 14.4 & 9.9 & 36.9 & 33.3 & 44.991 & $<0.001$ \\
\hline & 35-44 Yaş (n=59) & 23.7 & 0.0 & 27.1 & 44.1 & 18.085 & $<0.001$ \\
\hline & 45-54 Yaş $(n=36)$ & 19.4 & 8.3 & 36.1 & 36.1 & 8.000 & 0.046 \\
\hline & 55-64 Yaş $(n=18)$ & 5.6 & 0.0 & 22.2 & 66.7 & 18.000 & $<0.001$ \\
\hline & +65 Yaş (n=4) & 0.0 & 0.0 & 25.0 & 75.0 & 1.000 & 0.317 \\
\hline \multirow[t]{6}{*}{ Eğitim Düzeyi } & ilkokul (n=15) & 20.0 & 20.0 & 20.0 & 40.0 & 1.800 & 0.615 \\
\hline & Ortaokul (n=47) & 17.0 & 19.1 & 19.1 & 29.8 & 3.106 & 0.540 \\
\hline & Lise $(n=148)$ & 20.9 & 8.8 & 36.5 & 27.0 & 46.122 & $<0.001$ \\
\hline & Yüksekokul $(n=14)$ & 0.0 & 0.0 & 57.1 & 42.9 & 0.286 & 0.593 \\
\hline & Lisans $(n=148)$ & 20.3 & 8.1 & 35.1 & 32.4 & 57.676 & $<0.001$ \\
\hline & Lisansüstü (n=28) & 0.0 & 7.1 & 32.1 & 60.7 & 12.071 & 0.002 \\
\hline & & Kalabalıktan dolayı travertenlerin & yapısının dah & abuk bozulace & na inanıyorum & & \\
\hline Cinsiyet & Kadın $(n=136)$ & $\begin{array}{ll}1.5 & 16.9\end{array}$ & 8.8 & 36.8 & 36.0 & 69.074 & $<0.001$ \\
\hline & Erkek $(n=264)$ & 18.2 & 10.2 & 34.1 & 29.9 & 72.629 & $<0.001$ \\
\hline Medeni & Evli $(n=174)$ & 18.3 & 4.6 & 33.7 & 38.9 & 82.571 & $<0.001$ \\
\hline Durum & Bekâr (n=223) & 18.0 & 14.0 & 34.2 & 27.0 & 62.550 & $<0.001$ \\
\hline & Boşanmış $(n=3)$ & 0.0 & 0.0 & 0.0 & 100.0 & - & - \\
\hline Yaş & $18-24$ Yaş (n=172) & 23.3 & 13.4 & 33.7 & 23.3 & 37.709 & $<0.001$ \\
\hline & $25-34$ Yaş $(n=111)$ & 12.6 & 9.9 & 38.7 & 32.4 & 47.153 & $<0.001$ \\
\hline & $35-44$ Yaş $(n=59)$ & 16.9 & 5.1 & 33.9 & 39.0 & 29.729 & $<0.001$ \\
\hline & 45-54 Yaş $(n=36)$ & 16.7 & 2.8 & 47.2 & 33.3 & 16.222 & 0.001 \\
\hline & 55-64 Yaş $(n=18)$ & 5.6 & 5.6 & 11.1 & 72.2 & 30.889 & $<0.001$ \\
\hline & +65 Yaş $(n=4)$ & 0.0 & 0.0 & 0.0 & 100.0 & - & - \\
\hline Eğitim Düzeyi & illkokul (n=15) & 6.7 & 6.7 & 60.0 & 26.7 & 11.400 & 0.010 \\
\hline & Ortaokul (n=47) & 21.3 & 17.0 & 19.1 & 27.7 & 2.255 & 0.689 \\
\hline & Lise $(n=148)$ & 22.3 & 8.1 & 35.8 & 28.4 & 50.311 & $<0.001$ \\
\hline & Yüksekokul (n=14) & 0.0 & 0.0 & 50.0 & 50.0 & 0.000 & 1.000 \\
\hline & Lisans $(n=148)$ & 18.2 & 10.1 & 36.5 & 30.4 & 52.811 & $<0.001$ \\
\hline & Lisansüstü (n=28) & 0.0 & 10.7 & 28.6 & 60.7 & 10.786 & 0.005 \\
\hline & & Travertenlerdeki kararmaların ziyare & tçi yoğunluğı & lan kaynaklan & Inı düşünüyorum & & \\
\hline Cinsiyet & Kadın $(n=136)$ & 20.6 & 21.3 & 28.7 & 19.9 & 12.676 & 0.013 \\
\hline & Erkek $(n=264)$ & 19.7 & 21.2 & 24.6 & 18.6 & 5.508 & 0.239 \\
\hline Medeni & Evli $(n=174)$ & 14.9 & 7.4 & 34.3 & 38.3 & 6.229 & 0.183 \\
\hline Durum & Bekâr (n=223) & 20.3 & 11.7 & 36.0 & 26.1 & 10.928 & 0.027 \\
\hline & Boşanmış (n=3) & 0.0 & 0.0 & 0.0 & 100.0 & 0.000 & 1.000 \\
\hline Yaş & $18-24$ Yaş $(n=172)$ & 22.7 & 19.8 & 23.3 & 20.9 & 5.384 & 0.250 \\
\hline & 25-34 Yaş $(n=111)$ & 13.5 & 25.5 & 25.2 & 18.9 & 5.892 & 0.207 \\
\hline & $35-44$ Yaş $(n=59)$ & 18.6 & 22.0 & 30.5 & 11.9 & 5.661 & 0.226 \\
\hline & 45-54 Yaş $(n=36)$ & 27.8 & 16.7 & 36.1 & 16.7 & 11.500 & 0.021 \\
\hline & 55-64 Yaş $(n=18)$ & 22.2 & 22.2 & 27.8 & 16.7 & 1.444 & 0.836 \\
\hline & +65 Yaş $(n=4)$ & 25.0 & 0.0 & 0.0 & 75.0 & 1.000 & 0.317 \\
\hline Eğitim Düzeyi & İlkokul (n=15) & 20.0 & 6.7 & 26.7 & 33.3 & 3.333 & 0.504 \\
\hline & Ortaokul (n=47) & 19.1 & 27.8 & 17.0 & 17.0 & 1.830 & 0.767 \\
\hline & Lise $(n=148)$ & 22.3 & 18.2 & 23.0 & 20.9 & 2.811 & 0.590 \\
\hline & Yüksekokul (n=14) & 28.5 & 14.3 & 42.9 & 14.3 & 3.143 & 0.370 \\
\hline & Lisans ( $n=148)$ & 18.9 & 22.3 & 31.1 & 14.2 & 15.176 & 0.004 \\
\hline & Lisansüstü (n=28) & 10.7 & 32.1 & 21.4 & 32.1 & 9.143 & 0.058 \\
\hline
\end{tabular}


Alan içerisindeki ve yakın çevresindeki ulaşım ağlarının tarım alanları üzerinde farklı etkilere yol açabileceği düşünülmektedir. Alan çevresinde bulunan yollardan kaynaklanan toz, zararlı gaz ve partikül maddeler tarım alanlarında hem toprak yapısına hem de ürünlere zarar verebilecek niteliktedir. Pamukkale ÖÇKB içerisinde ören yerine özel araç girişi bulunmamaktadır. Ancak bu alanların sınırında bulunan ulaşım ağlarından kaynaklanan etkilerin azaltılması yönünde gerekli teknik ve biyolojik önlemlerin alınması önem taşımaktadır. Ayrıca bölgedeki gürültünün eşik sınıra çok yakın olması ve zaman içerisinde yeni yolların da yapılmasında bu etkinin dikkate alınması önem taşımaktadır. Tarım arazileri içerisinde yer alan ve koruma bölgelerine yakın olan bazı yerleşim bölgelerinin büyümelerinin sınırlandırılması gerekmektedir. Ayrıca bölgenin turizm potansiyelinin yüksek olmasından dolayı yeni turizm tesislerinin kontrollü inşa edilmesi turizmin sürdürülebilirliği açısından önem taşımaktadır. Bu araştırmada Pamukkale ÖÇKB'nde sorunların nelerden kaynaklandığı üzerinde durulmuştur. Öncelikle mevcut kullanımlardan kaynaklanan sorunların belirlenmesine odaklanılmıştır. Saptanan sorunlardan bazıları aşağıda sunulmuştur.

- Denizli kent merkezi ve sanayi tesislerinden kaynaklanan hava kirliliğinin travertenlerdeki kararmayı artırabileceği,

- Çevre ulaşım ağlarından kaynaklanan gürültünün insan sağlığını etkileyebileceği ve alandaki fauna varlığına zarar verebileceği,

- Çevre ulaşım ağlarının habitatlarda bozulmalara yol açacağı, bu nedenle hayvan ölümlerinin artabileceği,

- Tarım alanlarında kullanılan sulama suyu, gübre ve ilaç gibi kimyasalların çevre üzerinde olumsuz etki oluşturabileceği,

- Travertenlere verilen su miktarındaki düşüşlerin traverten oluşumunu azaltabileceği,

- Ziyaretçi yoğunluğuna bağlı artan katı atıkların görsel çevre kirliliğine neden olabileceği,

- Sanayi, turizm ve yerleşim alanlarının genişlemesi ile tarım arazilerinin kaybının artacağı,
- Pamukkale ÖÇKB’nin yakın çevresindeki diğer korunan alanlar ile ilişkisinin olmamasının alanın tahribatını hızlandırabileceği düşünülmektedir.

Denizli kentinin son yıllardaki nüfus artışı, yapılaşma hızı, kent içi ve yakınındaki sanayi tesisleri, ulaşım ağlarındaki gelişmeler, tarımsal etkinliklerden kaynaklanan faaliyetler Pamukkale ÖÇKB üzerinde doğrudan etkili olmaktadır. Bu etkiler alan içerisindeki turizm ve rekreasyon faaliyetlerinden kaynaklanan etkiler ile birleşince hissedilen etki düzeyi artmaktadır. Bu nedenle Pamukkale ÖÇKB içerisindeki sorunların ortadan kaldırılması için, kent ve ÖÇKB ile ilgili tüm planların dikkate alınması gerekmektedir.

Sonuç olarak hem tarihi kültürel özellikleri hem de doğal özellikleri nedeniyle uluslararası düzeyde öneme sahip olan çalışma alanı ve özellikle Pamukkale-Hierapolis Ören Yeri'nde bozulmaların en aza indirgenmesi, kaynakların korunması ve gelecek nesillere aktarılması ile alan içerisindeki ve çevresindeki sorunların ortadan kaldırılması için;

- Kent ve ÖÇKB ile ilgili tüm planların hazırlanmasında doğal ve kültürel peyzaj değerlerini dikkate alan bir yaklaşım izlenmeli,

- Alan kullanımlarının gerekliliği ve kapsamları ile doğal potansiyelin kullanımlara uygunluğu belirlenmeli,

- Alan kullanımları ile çevre faktörleri arasındaki ilişki değerlendirilmeli,

- Hassas ekosistemler ve korunması gereken alanlar saptanmalı,

- Peyzajın yapısını olumsuz etkileyebilecek kullanım ve faaliyetlere karşı alınacak önlemler ile peyzajın geliştirilmesi açısından yapılacaklar ortaya konulmalıdır.

\section{TEŞEKKÜR}

FYL-2016-1052 proje no ile bu araştırmayı destekleyen Akdeniz Üniversitesi Bilimsel Araştırma Projeleri Yönetim Birimi'ne teşekkür ederiz. 


\section{KAYNAKLAR}

Ahmad A, Ayob NM, Majid AA (2013) Regional Carrying Capacity (RCC) Issues Langkawi Islands, Kedah. Proceeding of International Conference on Tourism Development, Building the Future of Tourism 4-5 February 2013, pp 58-72.

Akçakoca Akça F., 2011. Bütün Eserleri 1. Kitap Küçük Denizli Tarihi. Ege Basım.

Bahadır M (2013) Kovada Gölü Milli Parkı́nın Sürdürülebilir Yönetimi. Doğu Coğrafya Dergisi, 18 (30): 287-310.

Bilim, Sanayi ve Teknoloji Bakanlığı (2015) https://osbbs.sanayi.gov.tr/citydetails.aspx?datalD=210 (Son erişim: 09 Mayıs 2015).

Castellani V, Sala S (2012) Carrying Capacity of Tourism System: Assessment of Environmental and Management Constraints Towards Sustainability. INTECH Open Access Publisher, pp 295316.

Coşkun T (2007) Cumhuriyet Dönemi Denizli'nin İdari Tarihi 19231973. Pamukkale Üniversitesi Sosyal Bilimler Enstitüsü Yüksek lisans Tezi, Denizli, $119 \mathrm{~s}$.

Çevre ve Şehircilik Bakanlığı http://www.csb.gov.tr/gm/tabiat/index.php?Sayfa=sayfa\&Tur=w ebmenu\&ld=19 (Son erişim: 10 Nisan 2014).

Denizli i̇l Gıda Tarım ve Hayvancılık Müdürlüğü (2015) Brifing Raporu.

Denizli il Kültür ve Turizm Müdürlüğü (2015) http://www.pamukkale.gov.tr/tr/Antik-Kentler (Son erişim: 09.05.2015).

Denizli Valiliği (2015) http://www.denizli.gov.tr/tarihce (Son erişim: 20.04.2015)

Doğa Koruma ve Milli Parklar Genel Müdürlüğü (2014) http://www.milliparklar.gov.tr/Anasayfa/istatistik.aspx?sflang=tr (Son erişim: 10.05.2015).

Doğaner S (1996) Anadolu'nun Coğrafi Mirası Pamukkale. Türk Coğrafya Dergisi 31: 7-38.

DOSB (2013) Denizli Organize Sanayi Bölgesi. http://www.dosb.org.tr/2/18/kurumsal/tarihce) (Son erişim: 09.05.2015)

Dunlap RE, Jorgenson AK, (2012) Environmental Problems. The WileyBlackwell Encyclopedia of Globalization, First Edition. Published by Blackwell Publishing Ltd.

GEKA (2014) Güney Ege Kalkınma Ajansı. TR32 Düzey 2 Bölgesi 20142023 Bölge Planı Mevcut Durum Analizi, Denizli.

Güner IN, Elhatip H (1999) Pamukkale Yöresi (Denizli) Termal Kaynaklarının Hidrokimyasal ve İzotopik İncelenmesi. Niğde Üniversitesi Mühendislik Bilimleri Dergisi, 3 (1): 35-47.
Güneş A (2012) Uluslararası Çevre Hukuku Üzerine Bir İnceleme. İstanbul Üniversitesi Hukuk Fakültesi Mecmuası. LXX, (1): 83-114.

KODAL T (2004) Cumhuriyetin İlk Nüfus Sayımına Göre Denizli'nin Nüfus Yapısı. Pamukkale Üniversitesi Eğitim Fakültesi Dergisi, 15(15), 62-72.

Kumsar H, Çelik SB, Kaya M (2004) Denizli ilı Merkezi Yerleşim Alanının Jeolojik, Jeoteknik Kent Bilgi Sistemi (JEO-KBS). Pamukkale Üniversitesi Mühendislik Fakültesi Mühendislik Bilimleri Dergisi, 10 (Özel Sayı): 25-31.

Kültür Varlıkları ve Müzeler Genel Müdürlüğü (2015) http://www.kulturvarliklari.gov.tr/TR,44974/illere-gore-sitalanlari-istatistigi.html (Son erişim: 09.05.2015).

Lantsova IV, Grigor'eva IL, Tikhomirov OA (2005) Geoenvironmental Problems of Recreational Use of the Ivankovo Reservoir. Journal of Water Resources, 32 (1): 107-113.

Malay H (1988) Antik Devirde Denizli Yöresinde Ekonomik Durum. Türk Kültür Tarihinde Denizli Sempozyumu, 28-30 Eylül 1988, Bilal Ofset, Denizli.

Mansuroğlu S (1999) Anadolu (İstanbul-Ankara) Otoyolunun Düzce Ovasında Tarım Toprakları Üzerine Etkilerinin Saptanması Üzerine Bir Araştırma. Abant İzzet Baysal Üniversitesi Araştırma Fonu, Proje No: 98.05.01.32, Düzce.

Pulido A (1972) Estadistica y Techicas de Investipacion Social. Ediciones Anaya, Madrid.

Savaş P (2011) Kentsel Mekanda Değişim: Denizli Kenti Örneği. 2. Kentsel ve Bölgesel Araştırmalar Sempozyumu, Ortadoğu Teknik Üniversitesi, Ankara, s 293-304.

Sütgibi S (2008) Doğal Ekosistemler Üzerinde İnsan Faaliyetlerinin Doğrudan ve Dolaylı Etkileri: Büyük Menderes Deltası. Marmara Coğrafya Dergisi, 18: 222-237.

Şahin M, Hacıömeroğlu S, Yıldız S, Biler L, Çetin B, Ketenoğlu O, Obalı O, Olgun K, Yiğit N, Kurt L, Kendir H, Gökgöz A, Çiçek M, Ergani E, Muratlı S, Güner AS, Tüzgen İ, (2010) Pamukkale Özel Çevre Koruma Bölgesi Biyolojik Çeşitliliğin Tespiti Projesi Sonuç Raporu. Çınar Mühendislik Müşavirlik ve Proje Hizmetleri Ltd. Şti., Ankara.

Şimşek C (2007) Laodikeia'dan Ladik'e Denizli. Uluslararası Denizli ve Çevresi Tarih ve Kültür Sempozyumu. Pamukkale Üniversitesi Fen Edebiyat Fakültesi Tarih Bölümü Yayınları, II. Cilt, s 38-51.

TÜiK (2017) https://biruni.tuik.gov.tr/medas/?kn=89\&locale=tr (Son erişim: 25.02.2017)

TÜiK (2016) https://biruni.tuik.gov.tr/medas/?kn=95\&locale=tr (Son erişim: 01.02.2016)

TÜiK (2013) Türkiye Tarım İstatistikleri Özeti, TÜiK Yayını.

UNESCO (2014) United Nations Educational, Scientific and Cultural Organization http://whc.unesco.org/en/list/485/ (Son erişim: 20.06.2015) 